\title{
ROS (Reactive Oxygen Species) and Nature
}

\author{
Shah Murad ${ }^{1 *}$, Seema Shah Murad ${ }^{2}$, Farid Ud Din ${ }^{3}$, Abdul Ghaffar ${ }^{4}$, Jamila Shah ${ }^{5}$ and Manal Rauf Mahar \\ ${ }^{1}$ Professor of Pharmacology, Pakistan \\ ${ }^{2}$ Gynecologist at NMC Karachi, Pakistan \\ ${ }^{3}$ Lecturer Pharmacology at DANTH Islamabad, Pakistan \\ ${ }^{4}$ CWO at IMDC and DANTH, Pakistan
}

${ }^{5}$ Psychologist at BU Karachi, Pakistan

${ }^{6}$ Dentist at IDH, Pakistan

*Corresponding author: Shah Murad, Professor of Pharmacology, Pakistan

\begin{abstract}
Oxidative stress, defined as a disturbance in the balance between the production of reactive oxygen species (free radicals) and antioxidant defenses, is discussed in relation to its possible role in the production of tissue damage in diabetes mellitus. Important free radicals are described and biological sources of origin discussed, together with the major antioxidant defense mechanisms. Examples of the possible consequences of free radical damage are provided with special emphasis on lipid peroxidation. Ginger (Zingiber officinale), a member of the Zingiberaceae family, is a popular spice used globally especially in most of the Asian countries. Chemical analysis of ginger shows that it contains over 400 different compounds. The major constituents in ginger rhizomes are carbohydrates (50-70\%), lipids (3-8\%), terpenes, and phenolic compounds. Terpene components of ginger include zingiberene, $\beta$-bisabolene, $\alpha$-farnesene, $\beta$-sesquiphellandrene, and $\alpha$-curcumene, while phenolic compounds include gingerol, paradols, and shogaol. These gingerols (23-25\%) and shogaol (18-25\%) are found in higher quantity than others. Besides these, amino acids, raw fiber, ash, protein, phytosterols, vitamins (e.g., nicotinic acid and vitamin A), and minerals are also present. We selected its hypolipidemic and weight lost effects in primary and secondary hyperlipidemic patients. Type of Research study: It was placebocontrolled study. Area of research: Research was conducted in Jinnah hospital, Lahore, Pakistan. Duration of study: It was three months, from January 2018 to June 2018. Material, Method and Results: Already well understood, clearly explained written consent was taken from sixty hyperlipidemic patients age range from 18 to 70 years. Both gender male and female patients were enrolled. Patients were randomly divided in two groups, 30 patients were on drug ginger pasted-powder advised to take 5 grams in divided doses with their normal diet for the period of three months. Thirty patients were on placebo pasted-wheat powder, with same color as of ginger powder, advised to take 5 grams in divided doses with their normal diet for the period of three months. Their base line lipid profile and body weight was recorded at start of treatment and were advised to come for check-up, fortnightly. When duration of study was over, their lipid profile and body weight was measured and compared statistically with pre-treatment values. Three months treatment with 5 grams of Ginger decreased LDL-cholesterol 17.41\%, total-cholesterol 8.83\% and body weight $2.11 \%$. When compared with placebo group, all changes in mentioned parameters were significant biostatistically. Conclusion: It was concluded from results of study that active ingredients of ginger lower plasma lipids and body weight significantly, eventually preventing development of coronary artery disease in primary and secondary hyperlipidemic patients.
\end{abstract}

\section{Introduction}

Oxidative stress reflects an imbalance between the systemic manifestation of reactive oxygen species and a biological system's ability to readily detoxify the reactive intermediates or to repair the resulting damage. Ginger is scientifically proved antioxidant agent. Ginger has been reported as a pain relief for arthritis, muscle soreness, chest pain, low back pain, stomach pain, and menstrual pain. It can be used for treating upper respiratory tract infections, cough, and bronchitis. As an anti-inflammatory agent, it is recommended for joint problems. Fresh juice of ginger has been shown to treat skin burns. Active component of ginger is used as a 
laxative and antacid medication. It is also used to warm the body for boosting the circulation and lowering high blood pressure. Because of its warming effect, ginger acts as antiviral for treatment of cold and flu. Ginger is also used as a flavoring agent in foods and beverages and as a fragrance in soaps and cosmetics. Cardiovascular diseases and stroke are complication of hyperlipidemia, diabetes mellitus, hypertension [1]. Many hypolipidemic drugs have already been proved to be useful in lowering serum lipid levels in patients.

However, its side effects in long term treatment were more reported and its prices were still expensive. Thus, efforts to develop effective and better hypolipidemic drugs had led to the discovery of natural medicinal herbs [2]. The beneficial uses of medicinal plants in traditional system of medicine of many cultures are extensively documented [3]. Several plants have been used as dietary adjuvant and in treating the number of diseases even without any knowledge on their proper functions and constituents [4]. Over $80 \%$ of the world population uses natural remedies as medicine and over $70 \%$ of doctors in Germany prescribe plant-based medicines [5]. Ginger (Zingiber officinale) is a natural dietary component, which has hypolipidemic, antiplatelet aggregation, antioxidant and anticarcinogenic properties [6]. Ginger is indigenous to southern China, spreading eventually to the Spice Islands, other parts of Asia and subsequently to West Africa and the Caribbean [7]. Ginger was exported to Europe via India in the first century AD as a result of the lucrative spice trade. India remains the largest producer of ginger [8]. Hypolipidemic and antiplatelet therapy is an effective approach for preventing coronary heart disease [9]. Ginger components are suggested as a potential new class of plateletactivation inhibitors without the potential side effects of aspirin, which is most commonly used in this approach. In a comparison of gingerols and analogs with aspirin, ginger compounds were found to be less potent compared to aspirin in inhibiting arachidonic acidinduced platelet release and aggregation and COX activity. However, several analogs had a significant inhibitory effect, suggesting that further development of more potent gingerol analogs might have value as an alternative to aspirin therapy in preventing ischemic heart disease $[10,11]$. Mechanism by which ginger may lower cholesterol is well understood by scientists and other researchers [12].

\section{Material and Method}

Research study was conducted at Jinnah hospital Lahore Pakistan, from January 2018 to June 2018. Written consent was taken from sixty hyperlipidemic patients age range from 18 to 70 years. Both gender male and female patients were enrolled. Patients were randomly divided in two groups, 30 patients were on drug ginger pasted-powder advised to take 5 grams in divided doses with their normal diet for the period of three months. Thirty patients were on placebo pasted-wheat powder, with same color as of ginger powder, advised to take 5 grams in divided doses with their normal diet for the period of three months. Their base line lipid profile (for total serum cholesterol, LDL-cholesterol ) and body weight was recorded at start of treatment and were advised to come for check-up, fortnightly. When duration of study was over, their lipid profile and body weight was measured and compared statistically with pre-treatment values. Serum total cholesterol was estimated by the enzymatic calorimatic method. Serum LDL-cholesterol was calculated by Friedwald formula (LDL-Cholesterol=Total Cholesterol-(Triglycerides/5 +HDL-Cholesterol). Body weight was determined by conventional method of usual weight machine Data were expressed as the mean \pm SD and paired " $t$ " test was applied to determine statistical significance as the difference. A probability value of $<0.05$ was considered as non-significance and $\mathrm{P}<0.001$ was considered as highly significant change in the results.

\section{Results}

Three months treatment with 5 grams of Ginger reduced LDL-cholesterol from $185.21 \pm 2.01$ to $157.72 \pm 1.90 \mathrm{mg} / \mathrm{dl}$, which is highly significant change in the parameter ( $\mathrm{p}$-value $<0.001$ ). Serum total cholesterol at baseline was $251.11 \pm 2.00 \mathrm{mg} / \mathrm{dl}$, which reduced to $230.71 \pm 1.77 \mathrm{mg} / \mathrm{dl}$. This change is highly significant statistically, with $\mathrm{p}$-value $<0.001$. Mean body weight decreased from $79.01 \pm \mathrm{kg}$ to $77.32 \pm 2.61 \mathrm{~kg}$ in three months therapy. All changes are highly significant statistically, having $\mathrm{p}$-value $<0.001$. In placebo group LDL-Cholesterol, serum total cholesterol and body weight reduction was $0.18,0.77$, and $0.22 \%$ respectively. All these changes are non-significant ( $p$-value $>0.05$ ). Detailed changes are shown in following.

\section{Key}

If \pm indicates standard error of mean, $p$-value $>0.05$ indicates non significant and $\mathrm{P}<0.001$ indicates highly significant change in lipid profile. LDL-C means low density lipoprotein cholesterol 0mg/ $\mathrm{dl}, \mathrm{T}-\mathrm{C}$ means total serum cholesterol $\mathrm{mg} / \mathrm{dl}$, and body weight is measured in $\mathrm{kg}$

\section{Discussion}

Oxidative stress, defined as a disturbance in the balance between the production of reactive oxygen species (free radicals) and antioxidant defenses, is discussed in relation to its possible role in the production of tissue damage in diabetes mellitus, hyperlipidemia, hypertension etc. In our research study ginger was used in thirty male and female hyperlipidemic patients for three months, which reduced LDLcholesterol from baseline value of $185.21 \pm 2.01 \mathrm{mg} / \mathrm{dl}$ to 157.72 $\pm 1.90 \mathrm{mg} / \mathrm{dl}$. It is $17.4 \%$ change in this parameter, which is highly significant change statistically with $p$-value of $<0.001$. These results match with results of Bordia A [13] who mentioned that nearly same effects of ginger may be achieved when the drug is used for three months. He has mentioned detailed explanations regarding effects of ginger in hyperlipidemic and hyperglycemic conditions. These results are in contrast with study results of Thomson M [14] who 
observed less effect on LDL-cholesterol, i.e.; from $179.57 \pm 2.29 \mathrm{mg} /$ $\mathrm{dl}$ to $176.92 \pm 2.11 \mathrm{mg} / \mathrm{dl}$ when they used three grams of ginger for the period of 6 months in 82 hyperlipidemic subjects (Table 1).

Table 1: Showing pretreatment, post treatment values, change in percentage and their statistical significance in DRUG GROUP $(n=27)$.

\begin{tabular}{|c|c|c|c|c|}
\hline Parameter & Pretreatment & $\begin{array}{c}\text { Post- } \\
\text { treatmentr }\end{array}$ & $\begin{array}{c}\text { Change } \\
\text { in \% }\end{array}$ & P-value \\
\hline LDL-C & $185.21 \pm 2.01$ & $157.72 \pm 1.90$ & $17.41 \%$ & $<0.001$ \\
\hline T-C & $251.11 \pm 2.00$ & $230.71 \pm 1.77$ & $8.83 \%$ & $<0.001$ \\
\hline Body weight & $79.01 \pm 3.01$ & $77.32 \pm 2.61$ & $2.11 \%$ & $<0.05$ \\
\hline
\end{tabular}

These variations and too much contrast in these two comparable studies may be sample size, long duration of administration of chemical compound/drug. In our observation serum total cholesterol reduced from $251.11 \pm 2.00 \mathrm{mg} / \mathrm{dl}$ to $230.71 \pm 1.77 \mathrm{mg} /$ dl. Vaes LP and Chyka PA [15] observed almost same changes in serum total cholesterol when they used 2 grams ginger powder, twice daily for the period of one month. Their results augment and support results of our research work. Our results in the parameter also match with results of study conducted by Kubasek $S$ [16] who observed same changes in serum total cholesterol (Table 2). Five grams of ginger in our study reduced body weight of $30 \mathrm{male} /$ female patients from $79.01 \pm \mathrm{kg}$ to $77.32 \pm 2.61 \mathrm{~kg}$ by 3 months therapy. Nurtjahja-Tjendraputra E [17] also observed same changes by their research study. This proves and augments our research results. Fuhrman B [18] described presence of various chemical ingredients in ginger which are responsible to decrease high levels of serum lipid levels and decreased blood pressure in hyperlipidemic patients. Our results are in contrast with study results of Guh J H [19] who proved that there is no significant effect on body weight when 2 grams of ginger powder daily was used for two months, in one hundred volunteers having secondary hyperlipidemia. Possible and guessed, scientific reason for this difference may be type of hyperlipidemia, ie; we included both primary and secondary hyperlipidemic patients, and they only included secondary hyperlipidemic patients.

Table 2: Showing pretreatment, post treatment values, change in percentage and their statistical significance in PLACEBO GROUP (n=30).

\begin{tabular}{|c|c|c|c|c|}
\hline Parameter & Pretreatment & $\begin{array}{c}\text { Post- } \\
\text { treatment }\end{array}$ & $\begin{array}{c}\text { Change } \\
\text { in \% }\end{array}$ & P-value \\
\hline LDL-c & $143.25 \pm 1.99$ & $142.98 \pm 2.61$ & $0.18 \%$ & $>0.05$ \\
\hline Tc & $190.47 \pm 2.71$ & $188.99 \pm 2.50$ & $0.77 \%$ & $>0.05$ \\
\hline Body weight & $76.73 \pm 2.19$ & $76.56 \pm 2.71$ & $0.22 \%$ & $>0.05$ \\
\hline
\end{tabular}

\section{References}

1. Lohar E, Kumar G, Srivastava A, Sharma SK, Gupta YK (2017) Safety evaluation of an Ayurvedic medicine, Arogyavardhini vati on brain, liver and kidney in rats. J Ethnopharmacol 12(9): 112-117.
2. Dudee W, Ramachandran A, Snehalatha C, Satyavani K, Sivasankari S, et al. (2010) Metabolic syndrome in urban Asian Indian adults: A population study using modified ATP III criteria 110(6): 1100-1106.

3. Kourounakis AP, Victoratos P, Perales N, Stefanou N, Jiangou M, et al. (2002) Experimental hyperlipidemia and the effect of NSAIDs. JMPR 2016 11(4): 112-116.

4. PE Schurr (2006) Triton-induced hyperlipidemia in rats as an animal model for screening hyperlipidemic drugs. Lipids 7: 68-74.

5. Farmer JA, Torre Amione G (2000) Comparative tolerability of the HMG CoA reductase inhibitors. Drug Saf 23(3): 197-213.

6. Ellen RL, McPherson R (1998) Long term efficacy and safety of fenofibrate and a statin in the treatment of combined hyperlipidemia. Am J Cardiol 81(4A): 60B-65B.

7. Lipscombe J, Lewis GF, Cattran D, Bargman JM (2001) Deterioration in renal function associated with fibrate therapy. Clin Nephrol 55(1): 3944.

8. Kluft C, De Maat MP, Gevers Leuven JA, Potter Van Loon BJ, Mohrschladt MF (1999) Statins and C reactive protein. Lancet 353(9160): 1200-1274.

9. Lagrand WK, Visser CA, Hermens WT, Niessen HW, Verheugt FW, et al. (1999) C-reactive protein as a cardiovascular risk factor: More than an epiphenomenon? Circulation 100(1): 96-102.

10. I Min Liu, Shorong Shii Liou, Ting Wei Lan, FengLin Hsu, Juei Tang Cheng (2005) Myricetin as the active principle of Abelmoschus moschatus to lower plasma glucose in streptozotocin induced diabetic rats. Planta Med 71(7): 617-621.

11. Kahlon TS, Chapman MH, Smith GE (2007) In vitro binding of bile acids by okra, beets, asparagus, eggplant, turnips, green beans, carrots, and cauliflower. Food chemistry 103(2): 676-680.

12. Fuhrman B, Rosenblat M, Hayek T, Coleman R, Aviram M (2000) Ginger extract consumption reduces plasma cholesterol, inhibits LDL oxidation, and attenuates development of atherosclerosis in atherosclerotic, apolipoprotein E-deficient mice. J Nutr 130(5): 1124-1131.

13. Bordia A, Verma SK, Srivastava KC (1997) Effect of ginger (Zingiber officinale Rosc) and fenugreek (Trigonella foenumgraecum $L$ ) on blood lipids, blood sugar, and platelet aggregation ion patients with coronary heart disease. Prostaglandins Leukot Essent Fatty Acids 56(5): 379-384.

14. Thomson M, Al Qattan KK, Al Sawan SM, Alnaqeeb MA, Khan I, et al. (2002) The use of ginger (Zingiber officinale Rosc.) as a potential antiinflammatory and antithrombotic agent. Prostaglandins Leukot Essent Fatty Acids 67(6): 475-478.

15. Vaes LP, Chyka PA (2000) Interactions of warfarin with garlic, ginger, ginkgo, or ginseng: nature of the evidence. Ann Pharmacother 34(12): 1478-1482.

16. Chrubasik S, Pittler MH, Roufogalis BD (2005) Zingiberis rhizoma: a comprehensive review on the ginger effect and efficacy profiles. Phytomedicine 12(9): 684-701.

17. Nurtjahja Tjendraputra E, Ammit AJ, Roufogalis BD, Tran VH, Duke CC (2003) Effective anti-platelet and COX-1 enzyme inhibitors from pungent constituents of ginger. Thromb Res 111(4-5): 259-265.

18. Fuhrman B, Rosenblat M, Hayek T, Coleman R, Aviram M (2000) Ginger extract consumption reduces plasma cholesterol, inhibits LDL oxidation and attenuates development of atherosclerosis in atherosclerotic, apolipoprotein E-deficient mice. J Nutr 130(5): 1124-1131.

19. Guh JH, Ko FN, Jong TT, Teng CM (1995) Antiplatelet effect of gingerol isolated from Zingiber officinale. J Pharm Pharmacol 47(4): 329-332. 
(C) (i) This work is licensed under Creative Commons Attribution 4.0 License

To Submit Your Article Click Here:

DOI: 10.32474/LOJPCR.2020.01.000124

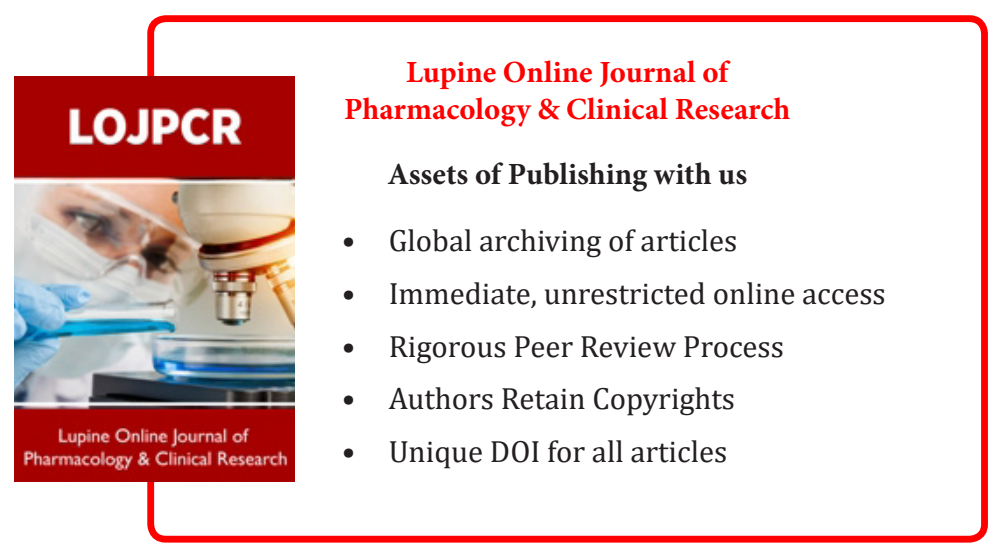

